Anna Więctawska*

Toruń

\title{
Poczucie sensu życia matek samotnie wychowujących dzieci
}

\section{Wstęp}

Doświadczanie sensu życia, ale i utrata jego poczucia są nieodłącznie związane z losem człowieka. Do uświadomienia poczucia sensu dochodzi jednostka na drodze przekraczania własnych uwarunkowań i odnoszenia się do wartości, w formie zaangażowania się w nie. Zagubienie wartości wywołuje obniżenie poczucia sensu życia. Mówiąc o sensie życia, mamy na myśli nie zwykłą celowość działań, lecz „znaczenie”, „ważność” życia jako czegoś godnego akceptacji. W rozumieniu V. E. Frankla, sens życia jawi się, realizuje, jest doświadczany tylko na poziomie osobowym.

W niniejszym artykule, oprócz analiz teoretycznych dotyczących poczucia sensu życia, przedstawione zostaną wyniki badań z zastosowaniem Skali Poczucia Sensu Życia (PIL) J. C. Crumbaugha i L. T. Maholicka (w szczególności analiza jakościowa tej skali), które przeprowadzono $\mathrm{z}$ udziałem dwóch grup nieletnich samotnych matek urodzonych po 1975 roku, z dziećmi do 5 lat. Kobiety, w momencie zaistnienia w ich życiu traumatycznego wydarzenia, jakim była nieplanowana wczesna ciąża, nie miały ukończonych 18 lat. Zbiorowość pierwszą (50 osób) stanowiły matki, które z różnych przyczyn umieszczono w Domach Samotnej Matki na terenie Polski (grupa A); drugą (również 50 osób) - matki, które wraz ze swoimi dziećmi mieszkają u swoich rodzin w Toruniu (grupa B). Przedstawione wyniki są fragmentem większych badań, jakie zostały przeprowadzone nad nieletnimi, samotnymi matkami (nie tylko w zakresie poczucia sensu życia) w okresie od lipca 1998 do marca $2000 \mathrm{roku}^{1}$.

\footnotetext{
* Dr Anna Więcławska - adiunkt, pracownik Instytutu Pedagogiki UMK w Toruniu.

${ }^{1}$ Badania nad nieletnimi samotnymi matkami zostały zaprezentowane w książce: A. Więcławska,
} 


\section{Poczucie i poszukiwanie sensu życia}

Pytania o sens życia, w szerszym rozumieniu, pytania o cel ludzkiego działania, o dobra godne pożądania, o szczęście człowieka, o znaczenie, jakie nadajemy życiu itp., są odwiecznymi pytaniami sięgającymi do głębi naszej egzystencji.

Sens życia poznajemy wtedy, gdy próbujemy odpowiedzieć na pytanie, po co i dlaczego istniejemy, kim być powinniśmy, do czego powinniśmy dążyć, co powinniśmy czynić, aby nasze życie było udane, sprawiedliwe i szczęśliwe, w jaki sposób możemy zapewnić sobie i światu lepszą przyszłość, w której warto jest naprawdę żyć?

Psychologiczne i socjologiczne pytania o sens świata i sens ludzkiego życia zostały sformułowane wyraźnie dopiero w czasach współczesnych i stały się „znakiem czasu” końca XX wieku. Coraz częściej rozumiemy, że fundamentalnych pytań dotyczących sprawiedliwości, wolności, miłości, sensu życia i śmierci, nie rozwiąże do końca nowoczesna nauka czy technika. Przybywa też ludzi, którzy stawiają zagadnienia jak najbardziej podstawowe, rozważają, kim jest człowiek, jaki jest sens cierpienia, zła, śmierci itp.

Poczucie sensu życia wiąże się u wielu osób z bezpośrednimi celami, będącymi w „zasięgu ręki”. Będą to m.in. bliskie kontakty z innymi ludźmi, świadomość bycia potrzebnym, aktywność zewnętrzna prowadząca do osiagnięcia zamierzonych efektów, poszukiwanie i odkrywanie prawdy, działalność w sferze politycznej, praca zawodowa, działalność twórcza. Niekiedy samo poszukiwanie sensu, nawet bez jego znalezienia, nadaje życiu ludzkiemu celowość i jakąś kierunkowość.

Jeżeli człowiek jest niepowtarzalną wartością, to jego decyzje dotyczące sensu życia nabierają szczególnej wagi. Pytanie o sens całego życia zakłada przekonanie, że taki sens powinno się mieć i że jest on do osiągnięcia poprzez dążenie ku wartościom. Sens całościowy, jako aprobująca decyzja w odniesieniu do całego życia, jest czymś więcej niż zwykłą sumą sensów jednostkowych. Jest on jakimś aktem wiary i nadziei człowieka w życie, ujętym w ramach całościowego horyzontu doświadczenia egzystencjalnego, refleksji nad własnym ,ja” i poszukiwaniem własnej tożsamości osobowej².

Przyjęcie i zaakceptowanie sensu życia ludzkiego i sensu własnego życia nie jest łatwym zadaniem, szczególnie dla niektórych ludzi. Sens nie jest dany, ale trzeba go poszukiwać. Poszukiwanie to jest okupione wielkim trudem i wysiłkiem, gdyż nieraz trzeba pokonywać ogromny trud niepewności i wątpienia. Trud szukania sensu własnego życia i życia ludzkiego uwarunkowany jest wieloma czynnikami takimi, jak: osobowość, inteligencja, środowisko, przeżywane kryzysy osobiste, sposoby radzenia sobie w sytuacjach trudnych itp. Są ludzie, którzy mają wiele problemów ze znalezieniem sensu życia. Zdarza się, że raz znaleziony dewaluuje się, podawany jest

Nieletnie dziewczęta samotnie wychowujace dzieci a ich przygotowanie do radzenia sobie z ograniczeniami losu. Diagnoza stanu kompetencji, Torun 2005.

${ }^{2}$ A. Siciński, Życie codzienne w latach 70. (refleksje), w: Siciński A. (red.), Styl życia w miastach polskich (u progu kryzysu), Wrocław-Warszawa-Kraków-Gdańsk-Lódź 1988, s. 340. 
w wątpliwość, staje się niewystarczający w sytuacjach kryzysu. Człowiek podlega także specyficznym kryzysom wartości, czy nawet tzw. kryzysom sensu życia, wtedy właśnie występuje poczucie bezsensu życia, co łączy się z beznadziejnością i towarzyszą temu przeżyciu, np. tendencje samobójcze ${ }^{3}$.

Brak sensu życia lub jego utrata jest zagrożeniem dla życia człowieka i zagrożeniem dla jego zdrowia psychicznego. Oznacza zagubienie racji bytu i znalezienie się w pustce egzystencjalnej.

W psychologii egzystencjalnej (w szczególności w nooteorii) przyjmuje się, że sens egzystencjalny wiąże się z przeświadczeniem, że wszystko, co istnieje ma swój sens, choć nie zawsze potrafimy go ukazać, a nawet do końca zrozumieć.

Problematyka sensu ludzkiego życia stanowi centrum zainteresowań psychologów egzystencjalnych. Ich zdaniem, utrata poczucia sensu życia ma dla egzystencji charakter patogenny.

Według V. E. Frankla, człowiek spełnia sens bytu ludzkiego, wypełnia swój byt sensem zawsze dzięki temu, że urzeczywistnia wartości. Można to czynić w trojaki sposób. Pierwszym sposobem urzeczywistniania wartości jest działanie, jakieś kształtowanie świata. Druga możliwość polega na przeżywaniu świata, wchłanianiu, przyswajaniu sobie piękna i prawdy bytu. Trzecia wreszcie możliwość urzeczywistniania wartości - to cierpienie, znoszenie losu, bytu.

V. E. Frankl (a także inni psychologowie egzystencjalni np. R. May czy K. Popielski) rozpatrują człowieka jako istotę skierowaną do sensu, będącą w ciagłym jego poszukiwaniu, przy czym poczucie sensu życia jest zawsze doświadczane z kimś lub z czymś. Wartości egzystencjalnie ważne muszą mieć charakter wartości podmiotowo znaczących; muszą zaistnieć w świadomości i przeżyciu podmiotu - stać się ważne i znaczące w doświadczaniu egzystencji. Wartości te stają się szczególnie istotne w cierpieniu człowieka, kiedy „,cierpiący nie jest już zdolny kształtować swój los zewnętrznie...” V. E. Frankl mówi jednak, że „Los sam w sobie niewiele znaczy: tym co los zrządził, człowiek musi dopiero rozporządzić"4.

Nie tylko przez dzielność w cierpieniu człowiek dąży i poszukuje sensu. Także własny sukces można wykorzystać w niesieniu pomocy ludziom cierpiącym dla złagodzenia ich cierpienia. Poszukiwanie i odkrywanie sensu w sytuacji własnego sukcesu i szczęścia istnieje w gotowości do pomocy innym. Tak więc sens życia polega na twórczym ustosunkowaniu się do własnego bytowania. Sens odkrywa człowiek zawsze w relacji do wartości, zaś utrata poczucia sensu łączy się najczęściej z brakiem wartości znaczących dla egzystencji - z brakiem ich hierarchizacji, z wyborem wartości służących jakiejś potrzebie, a nie egzystencji.

Tak więc człowiek walczy o sens, ale nie tylko sens cierpienia. Walczy o sens życia w ogóle, o sens egzystencji. Ważna jest walka o sens bytu ludzkiego i o pomoc w znalezieniu tego sensu; ważne jest orientowanie się człowieka „na sens” i dążenie „ku” wartościom.

${ }^{3}$ Z. Płużek, Osobowościowe uwarunkowania pytania o sens życia, w: K. Popielski (red.), Człowiek-wartości-sens, Lublin 1996, s. 366.

${ }^{4}$ V. E. Frankl, Homo patiens, Warszawa 1998, s. 290. 
Sens egzystencjalny łączy się z przekonaniem o sensowności i celowości własnego (jednostkowego) życia. Źródłem takiego poczucia jest doświadczenie sensu w życiu osobistym, w konkretnych sytuacjach życia w perspektywie oceny przeżyć, wyborów, decyzji i działań. Wielowymiarowo przeżywane sens i sensowność są doświadczeniem naturalnym, wstępnym dla osiąnnięcia podmiotowo-osobowego przeświadczenia o ,rzeczywistości sensu”. To poczuciejest potrzebą i dążeniem stałym w i dla ludzkiej egzystencji ${ }^{5}$.

Termin ,poczucie” jest miarą doznania i doświadczenia (m.in. sensu życia). jest wyrazem jego akceptacji oraz siły i nastawien „ku...” życiu. Samo pojęcie „poczucie” jest terminem na określenie procesu fuzji emocjonalno-poznawczej i to niezależnie od tego, że jego odcień semantyczny sugeruje raczej uczucie, niż znaczenie.

Poczucie sensu życia zawiera w swojej strukturze następujące komponenty ${ }^{6}$ :

- intelektualny, który odnosi się do poznania natury życia ludzkiego, środowiska i celów osobistych. Implikuje to równocześnie zdolność jednostki do poznawania swej własnej natury, historii swego życia, otoczenia. Jakikolwiek brak w tym względzie obniża intensywność poznawczą rozumienia siebie i poczucia sensu.

- emocjonalno-uczuciowy, związany jest ze zdolnością do doświadczania siebie, do reagowania na wartości, a wśród nich na własne przegranelub osiągnięcia, dążenia, sukcesy.

- wolitywno-dążeniowy, wiąże się z uzdolnieniem człowieka do dokonywania wyborów i przyjmowania postawy. Mówimy o osobowej kondycji jednostki do działania jako wolnej oraz zdolności do podporządkowywania się pociągającym wartościom i podporządkowywania się ich hierarchii.

- egzystencjalno-działaniowy, identyfikowany jest w podwójnym aspekcie: jako przyczyna zaistnienia poczucia sensu życia i jako efekt jego istnienia. Jest to wyraz osobowego „tak” powiedzianego konkretnemu życiu, zaangażowania się w nie i działania na rzecz jego budowania.

Poczucie sensu życia jest:

1. Związane bezpośrednio z podmiotowym i indywidualnym doświadczeniem jednostki. Integruje jednostkę wewnętrznie i motywuje „ku” życiu,

2. Pośrednio warunkowane strukturą osobowościową jednostki, jej osobowymi celami i dążeniami. Na jego rodzaj duży wpływ wywiera środowisko społeczne i przyrodnicze,

3. Charakteryzuje się: zindywidualizowanym rozwojem, dużą stabilnością, jest najgłębszą siłą motywującą egzystencję.

Możemy rozróżnić sens życia:

- funkcjonalny, istnieje wówczas, gdy coś ma znaczenie ze wzglądu na jakiś inny zewnętrzny cel,

${ }^{5}$ K. Popielski, Psychologiczno-egzystencjalna interpretacja problematyki sensu i sensowności, w: K. Popielski (red.), Człowiek-wartości-sens..., s. 50-51.

${ }^{6}$ Tenże, ,, Sens” $i$,, wartość” życia jako kategorie antropologiczno-psychologiczne, w: K. Popielski (red.), Człowiek - pytanie otwarte, Lublin 1987, s. 135-136. 
- subiektywny, rodzi się w doświadczeniu podmiotowym i ma odniesienie i ważność w konkretnym życiu i dla konkretnej jednostki,

- obiektywny, mamy z nim do czynienia, gdy obiektywnie sensowne czyny czy odniesienia prowadzą do zaistnienia podmiotowo doświadczanego poczucia sensu. Związany jest z pozytywnie nastawionym myśleniem, celami i działaniami. Sens obiektywny ma rację swego istnienia sam w sobie i nie jest zależny od żadnego celu leżącego na zewnątrz.

Egzystencjalne poczucie sensu jest swoistym, indukcyjnym uogólnieniem doświadczeń sensowności konkretnych doznań, przeżyć, spraw i zdarzeń w konkretnych sytuacjach życiowych. Empiryczną podstawą do urobienia sobie przeświadczenia o ,sensie” jest rzeczywistość wielowymiarowego funkcjonowania potrzeb i tego, że coś dla czegoś (i kogoś) jest znaczeniem i uzasadnieniem konkretnego działania, jego podjęcia lub zaniechania ${ }^{7}$.

Zatem sens i sensowność nie są tylko subiektywno-podmiotowymi kategoriami wyrażającymi stosunek do świata zdarzeń i przedmiotów. Sens zdaje się być wbudowany w życie, w ludzki świat potrzeb, obserwacji, percepcji, dążeń, odniesień i aktywności. Sens nie jest tworem człowieka, a raczej doświadczeniem odkrywanym w procesie życia, jako coś, co istnieje w nim jako potrzeba, ale również i jako tego rodzaju rzeczywistość poza nim samym, która tę potrzebę potrafi wypełnić. W tym sensie K. Popielski formułuje myśl o sensie jako „potrzebie potrzeb”, jako charakterystyce i właściwości każdej potrzeby realizującej się w napięciu: podmiot - podmiot i podmiot - przedmiot $^{8}$.

W rozumieniu V. E. Frankla, sens życia jawi się, realizuje, jest doświadczany tylko na poziomie osobowym. Dla egzystencji jest on właściwością pierwotną ludzi. Niemniej jednak jego urzeczywistnianie się jest złączone z przebiegiem i dynamiką jednostkowego rozwoju. Na innym poziomie bytowania jest on niedostępny. Pytanie o sens u ludzi jest cechą gatunkową. Człowiek pyta nie tylko o sens własnej egzystencji, ale i o sens świata, sens kosmosu i wreszcie o sens sensu?

W egzystencjalnym ujęciu kategorie sensu obiektywnego i podmiotowego rozumiane są jako wyrażenia dotyczące rzeczywistości koniecznej dla prawidłowego funkcjonowania i rozwoju psychiki ludzkiej. Stanowi rodzaj fundamentu i zasadniczego punktu odniesienia dla odczytywania sensowności i jednostkowo doświadczanego sensu.

Sens życia w egzystencjalnym odczytaniu funkcjonuje jako kategoria antropologiczno-psychologiczna o charakterze finalnym i celowościowym. Znaczy to, że poszczególne ciągi celów i wartości oraz procesy dążeń i odniesień, łączą się w większe całości egzystencjalno-kognitywne, życiowo ważne i egzystencjalnie znaczące.

${ }^{7}$ PK. Popielski, Psychologiczno-egzystencjalna interpretacja problematyki sensu i sensowności..., s. 52.

${ }^{8}$ Tamże, s. 52

${ }^{9} \mathrm{~K}$. Popielski, „Sens” $i$,,wartośc’” życia jako kategorie antropologiczno-psychologiczne..., s. $133-134$. 
Człowiek jako istota społeczna z natury swojej nastawiony jest na drugiego człowieka. Rozwój człowieka realizuje się i aktywizuje poprzez bycie z innymi, z kimś drugim. Człowiekowi potrzebne jest to przeżycie, że dla kogoś jest ważny, znaczący, kochany, brany pod uwagę i że to przeżywanie ma cechę zwrotności. Proces ten realizowany jest na każdym $\mathrm{z}$ etapów rozwojowych i przebiega zawsze w określonym kontekście społecznym. Nikt bowiem nie jest samotną wyspą. Poczucie, że jest się kimś, kto liczy się z innymi i dla innych ma zasadnicze znaczenie dla rozwoju osobowego ,ja”, doświadczania więzi z innymi ludźmi i dla przeżywania własnej podmiotowości.

Drogą do kształtowania, podtrzymywania i rozwijania tak rozumianej więzi międzyosobowej jest wchodzenie w takie interakcje, które określane są mianem poprawnej, dojrzałej komunikacji ${ }^{10}$. Kontaktując się z innymi ludźmi, człowiek zyskuje nie tylko umiejętności i zdrowie, ale także zrozumienie, czym jest sam. Osiaga świadomość własnej godności.

Konstruktywne związki międzyosobowe stanowią zasadniczą podstawę poznawania siebie, adekwatnej samooceny, są niezbędne dla zaspokojenia potrzeb, np. bezpieczeństwa, przynależności czy samorealizacji. Podmiotowo-osobowe odniesienia uczestników interakcji stanowią wreszcie o tym, że człowiek doświadcza poczucia satysfakcji z realizowania siebie i swojego rozwoju. W tym znaczeniu dojrzała komunikacja międzyosobowa ma znaczenie sensotwórcze. Sens życia może być zdefiniowany jako poczucie satysfakcji z realizowania własnego rozwoju i z pozostawania w bliskich związkach z innymi ludźmi. Nie jest bowiem celem naszego rozwoju „kompletowanie" własnego ,ja”, ale przekraczanie go na rzecz innych. Osobowe ,ja” staje się wówczas zdolne do transcendowania ku osobowemu „ty”"1. Obecność i doświadczanie elementu społecznego w postaci „ty” jest niezbędne dla doświadczania mojego „ja”. Człowiek staje się ,ja” w kontakcie z „ty”. Psychika ludzka jest więc naturalnie ukierunkowana na poszukiwanie wartości w obszarze relacji interpersonalnych. Odnajdywanie i doświadczanie tych wartości jest ważnym źródłem poczucia sensu życia. Z kolei utrata tych wartości wywołuje stres z istotnym rezonansem wywołującym obniżenie poziomu poczucia sensu życia ${ }^{12}$.

Doświadczenie sensu życia, ale i utrata jego poczucia są nieodłącznie związane z losem człowieka. Twórcy wielkich systemów psychologicznych mieli różny stosunek do tego faktu. Freud wypowiadał się o potrzebie sensu jako o przejawie choroby. Jung uważał, że rzeczywiście, w związku z problemem sensu człowiek reaguje chorobą (nerwica), ale nie na skutek jego potrzeby, a braku. Franklowi przypadło ukazanie znaczenia sensu dla życia osobowego, dla satysfakcji z niego i dla zdrowia

${ }^{10} \mathrm{~W}$. Okła, Interakcyjne uwarunkowania poczucia sensu życia, w: K. Popielski (red.), Człowiek-wartości-sens..., s. 419.

${ }^{11}$ Tamże, s. 420.

12 W. Prężyna, Społeczno-religijne odniesienia dla poczucia sensu życia i psychoterapii, w: K. Popielski (red.), Człowiek-wartości-sens, s. 375. 
człowieka. Zwykle po opanowaniu przez człowieka odpowiedzi na pytanie ,jak” żyć, staje przed nim pytanie „dlaczego” żyć ${ }^{13}$.

Brak woli życia wiąże się ściśle z lękiem, przy czym jest to lęk przed bezsilnością brakiem umiejętności, niepowodzeniem i popełnieniem błędu. Jest to lęk powiązany z utratą tożsamości - z trudnością w określaniu „kim jestem”.

Zdaniem B. Hołysta, utrata tego, co stanowiło do niedawna dla jednostki cel jej dążeń i działań, prowadzi do niezaspokojenia potrzeby sensu życia, wytworzenia przekonania o beznadziejności dotychczasowych poczynań i poczucie bezsensu życia. Zatem ważny jest realizm samooceny człowieka. Jednak zawyżony obraz samego siebie, powodując potrzebę nieustannych osiaggnięć, ciaggego wyróżniania się i dominacji, stanowi podatny grunt do powstania obiektywnej i subiektywnej sytuacji osamotnienia. Także zaniżona samoocena, rodząc brak zaufania do siebie i nieśmiałość, może w konsekwencji doprowadzić do izolacji społecznej i poczucia osamotnienia. Można zatem z dużym prawdopodobieństwem przewidzieć, że u niektórych osób z nierealnym obrazem własnego ,ja”, połączonym z poczuciem niskiej wartości, pogłębia się poczucie osamotnienia, a potrzeba sensu życia może ulec silnej destrukcji ${ }^{14}$.

W modelu kognitywnym głównymi cechami charakteryzującymi poznawcze nastawienie człowieka tracącego wolę życia jest negatywna postawa wobec własnej osoby oraz zniekształcona rzeczywistość. Ta ostatnia odbywa się w powiązaniu z interpretacją dotychczasowych doświadczeń oraz negatywnym spostrzeganiem przyszłości.

Inne stanowisko prezentuje V. E. Frankl. Według tego autora, brak motywacji do realizacji sensu życia jest konsekwencją niedostatku wartości egzystencjalnych, ich niedojrzałości lub niemożności ich realizacji, która prowadzi do wystąpienia tzw. nerwicy noogennej. Zaburzenia nerwicowe zależą od egzystencjalnego wymiaru człowieka, wyrażającego się w kategoriach wolności i odpowiedzialności. Jest to wymiar noetyczny, którego przejawy w postaci konfliktów moralnych i kryzysów egzystencjalnych mogą być poważnymi czynnikami nerwicorodnymi (nerwicy noogennej). Kryzys czy konflikt jako taki, sam w sobie nie jest patogenny, gdyż wynika z dążenia do poszukiwania sensu istnienia i realizacji wartości, co ma przecież znaczenie pozytywne. Natomiast patogenne dążenie do znalezienia sensu ujawnia się wówczas, gdy w jego rezultacie rodzi się „stan niespełnienia”, porażki, rezygnacja z dążenia i walki o to, by swemu życiu nadać wartość. Człowiek uznaje wówczas swoje istnienie za bezsensowne - pojawia się „egzystencjalna pustka”, „egzystencjalna próżnia”"15. Niespełnienie potrzeby sensu życia rodzi frustrację egzystencjalną, którą należy traktować jako metapatologię. Charakteryzuje się ona utratą poczucia sensu dotyczącego obowiązków człowieka, celów i wartości. Towarzyszy temu poczucie ograniczonej perspektywy życiowej, odczucie wewnętrznej pustki i nudy. Świat jest postrzegany jako absurdalny i bezsensowny. Zaburzenia te V. E. Frankl wiąże z patologią ducha czasu.

${ }^{13}$ K. Popielski, ,Sens” $i$,,wartość” życia jako kategorie antropologiczno-psychologiczne..., s. 136.

${ }^{14}$ B. Hołyst, Przywróceni życiu, Warszawa 1991, s. 132-134.

${ }^{15}$ V. E. Frankl, dz. cyt., s. 135. 
W zbliżony sposób problem utraty sensu życia ujmuje K. Dąbrowski. Uważa on, że każdy staje się człowiekiem w trakcie swego życia, dzięki wyborom i realizowaniu wartości egzystencjalnych. Utratę sensu życia wiąże zaś z brakiem przekonania o pozytywnej wartości własnej działalności życiowej, z brakiem, któremu towarzyszy stan negatywnych emocji ${ }^{16}$.

Badania wykazują że oprócz zagrożenia, jakie niesie ze sobą utrata poczucia sensu życia, niebezpieczna jest także postawa ambiwalentna wobec niego. Ktoś mówi: ,życie ludzkie ma swoją wartość, nie jest pozbawione sensu - ale moje życie takie nie jest”, „życie każdego człowieka jest wartościowe i sensowne, moje także, ale... ja nie mam siły żyć i borykać się z trudnościami, już mi się nie chce...”"17.

Stopniowa utrata sił ekspansywnych oraz mechanizmów obronnych prowadzi, zdaniem E. Ringela, do syndromu suicydalnego. Człowiek uznaje, że sytuacja, w której się znalazł, jest niesamowita, trudna, nie da się jej przezwyciężyć, a on sam jest istota bezradną, bezsilną, zdaną na łaskę losu. Pojawia się panika, strach, zawężenie się sfery emocjonalnej oraz agresja wobec siebie ${ }^{18}$.

Utratę poczucia sensu życia łączy się najczęściej z brakiem wartości znaczących dla egzystencji, z ich niedojrzałością czy brakiem hierarchizacji, z wyborem wartości służących jakiejś potrzebie, a nie egzystencji, nie wykształtowaniem się idei wiodących, z niemożnością kształtowania osobowego stylu życia. Łączy się ją także z patologią ducha czasu, z dewiacjami cywilizacji.

Utraconego sensu życia nie można leczyć ingerencją wprost. Można natomiast i trzeba stwarzać warunki, w których dynamizm sensu i wartości życia mógłby się realizować.

\section{Intensywność poczucia sensu życia}

Analiza jakościowa poczucia sensu życia przy zastosowaniu Skali Poczucia Sensu Życia - PIL J. C. Crumbaugha i L. T. Maholicka

Skala Poczucia Sensu Życia J. C. Crumbaugha i L. T. Maholicka, która została zastosowana do badania poczucia sensu życia, powstała na bazie założeń teoretycznych właśnie V. E. Frankla. Służy ona do pomiaru intensywności celów życiowych i pośrednio do pomiaru poczucia sensu życia.

Składa się z trzech części. Część A - metryczna, zawiera 20 par stwierdzeń, do których badany ustosunkowuje się na skali 7-stopniowej - od 1 (niski sens) do 7 (wysoki sens); suma punktów przyporządkowanych wszystkim stwierdzeniom jest wskaźnikiem liczbowym poczucia sensu życia badanego, przy czym wynik maksymalny równa się 140, zaś minimalny 20; za wyniki wysokie uznane są przedziały od 111

\footnotetext{
${ }^{16}$ K. Dąbrowski, W poszukiwaniu zdrowia psychicznego, Warszawa 1996, s. 159-167.

${ }^{17}$ Z. Płużek, Osobowościowe uwarunkowania pytania o sens życia, w: K. Popielski (red.), Człowiek-wartości-sens..., s. 370.

${ }^{18}$ E. Ringel, Gdy życie traci sens. Rozważania o samobójstwie, Warszawa 1987, s. 57-58, 209-210.
} 
punktów wzwyż - osoby zdrowe uzyskują wyniki powyżej 100 punktów, natomiast grupy kliniczne poniżej 100 punktów; oraz dwie następne części, stanowiące wypowiedź zdań niedokończonych i zachętę do wypowiedzi wolnej dotyczącej dążeń, ambicji i celów w życiu, pozwalające na przeprowadzenie analizy jakościowej ${ }^{19}$.

W czasie badań prosimy jednak, aby w części A badana zaznaczyła tę cyfrę, która najpełniej określa natężenie jej aprobaty lub dezaprobaty wobec danego twierdzenia oraz aby raczej unikała wyboru „neutralnego”, tj. cyfry 4. Jest to sposób oceniania wykorzystujący techniki skal szacunkowych. W skali przy poszczególnych twierdzeniach zmienia się kolejność punktowania, celem ograniczenia zjawiska „halo - efektu" i preferencji pozycji. Oznacza to, że raz cyfry biegną w porządki od 1 do 7 , innym razem w porządku malejącym od 7 do $1^{20}$.

$\mathrm{Na}$ dokonanie analizy jakościowej, którą to właśnie przedstawię szczegółowo w dalszej części artykułu, pozwalają z kolei część „B” i „C” Skali Poczucia Sensu Życia (PIL). Części te mają charakter wypowiedzi zdań niedokończonych.

Wykorzystując podobieństwa treściowe poszczególnych zdań znajdujących się w częściach „B” i „C”, połączono je i otrzymano grupy wypowiedzi, które pomogły wnioskować o: stosunku badanych do własnego życia, rodzaju posiadanego celu życia, zadowoleniu badanych z realizacji posiadanych celów, posiadanej nadziei, ambicji, interpretacji dotyczącej ofiarności i pomocy ze strony innych ludzi oraz indywidualnego nadawania sensu swojej egzystencji ${ }^{21}$.

Obecnie prześledzimy grupy wypowiedzi odnoszących się do powyższych aspektów życia badanych.

\section{Stosunek badanych do własnego życia}

Badane matki wypowiadały się w tej części kończąc zdania: „Moje życie jest...”, „Życie jest dla mnie...” Przy ocenie wypowiedzi brałam pod uwagę treść zawartą w każdej z nich, ale i kryterium pozytywnego bądź negatywnego ustosunkowania się badanych do własnej egzystencji.

Na pierwsze z postawionych pytań matki z Domów Samotnej Matki odpowiadały najczęściej, że ich życie jest: „wielką grą”, „ciężkie”, ,rozkołatane”, „nieudane”, „smutne i pełne łez”, „skomplikowane”, ,pogmatwane”, „bezsensowne”, „do kitu”, „głupie”, „monotonne”, „,ciagłą tułaczką”, „okropne”, ,puste”, „beznadziejne”.

Były też wypowiedzi świadczące o pozytywnym podejściu do własnego życia, lecz było ich zdecydowanie mniej. Matki wypowiadały się, że ich życie jest: „piękne”, „udane”, ,radosne”, „ciekawe”, ,pogodne, bo ma się dla kogo żyć”.

${ }^{19}$ T. Borowska, Pedagogia ograniczeń ludzkiej egzystencji, Warszawa 1998, s. 121.

${ }^{20} \mathrm{~K}$. Popielski, Testy egzystencjalne: metody badania frustracji egzystencjalnej i nerwicy noogennej, w: K. Popielski (red.), Człowiek - pytanie otwarte..., s. 242-243.

${ }^{21}$ Nazwy tych kategorii zostały zaczerpnięte z książki T. Borowskiej, Pedagogia ograniczeń ludzkiej egzystencji, Warszawa 1998. Autorka również wykorzystała w swoich badaniach Skalę Poczucia Sensu Życia PIL. 
Na to samo pytanie matki pozostające we własnych rodzinach odpowiadały, że życie jest: „,monotonne”, ,biedne i nerwowe”, ,smutne”, ,pełne obowiązków i udręk”, ,,szare”, „,normalne”, „,dobre”, ,piękne”, „pełne niespodzianek”, „wspaniałe”, „ciekawe”, „kolorowe”, „urozmaicone”, „szczęśliwe”, ,z dnia na dzień ciekawsze”, ,udane”.

Na pytanie drugie „Życie jest dla mnie...” matki z DSM odpowiadały: ,skomplikowane”, ,wielką udręką”, „monotonne”, „bez sensu”, ,walką o wszystko”, ,niesprawiedliwe”, „ciężkie”, ”przekreślone”, „drogą pełną przeszkód”, „,szare”, ale i „,czymś bardzo ważnym”, ,cudem”, „,darem”, „,nauką”, ,wielkim wyzwaniem”, ,wędrówką”, ,jest ciekawe”, „super”.

Dla samotnych matek z grupy B życie jest: „,najważniejsze”, „czymś cennym i pięknym”, „dobrodziejstwem”, „szansą”, „, darem”, ,skarbem”.

Oceniając stosunek badanych matek do własnego życia, można powiedzieć, iż wypowiedzi matek z grupy drugiej wykazują bardziej pozytywny stosunek do życia i własnej egzystencji w porównaniu z matkami z DSM.

\section{Cele życiowe i zadowolenie $\mathrm{z}$ ich realizacji}

O posiadanych celach świadczą wypowiedzi badanych np.: „Jedynym celem mojego życia jest...”, „Moją największą ambicją jest...”, „,Więcej niż czegokolwiek w życiu pragnąłbym..."

Generalnie badane grupy nie wykazują różnic w wypowiedziach na temat swoich celów życiowych i pragnień.

Ich celem życia, ambicją i pragnieniem jest: miłość, bezpieczeństwo, spokój, szczęście rodziny, chęć stworzenia normalnej rodziny, wychowanie dzieci na dobrych ludzi, zapewnienie jak najlepszego bytu i wykształcenia własnemu dziecku, własne mieszkanie (częściej u matek z DSM), posiadanie pieniędzy i dobrej pracy, a także dalsze kształcenie. W wypowiedziach matek z DSM pojawiały się także zdania dotyczące chęci spotkania z własnymi matkami, czy odzyskanie zaufania rodziny.

\section{Stosunek badanych do choroby, cierpienia i śmierci}

Stosunek człowieka do własnej egzystencji wyraża się także w poglądach na temat cierpienia, choroby i śmierci. Badane matki wyraziły swoje zdanie na temat tych trzech doświadczeń, kończąc myśli: „Najbardziej beznadziejną rzeczą jest...”, „Choroba i cierpienie mogą być...” oraz „Śmierć jest...”

Można powiedzieć, że obie grupy matek wypowiadały się na powyższe pytania w podobny sposób.

Za najbardziej beznadziejne rzeczy uważały: „niezrozumienie w rodzinie”, „nieżyczliwość ludzi”, „nietolerancję”, ,życie bez przyjaźni”, „bezsilność”, „samotność”, „utratę bliskich”, „załamywanie się ciężką sytuacją”, „użalanie się nad sobą”, ,popa- 
danie w nałogi” „biedę”, „brak swojego mieszkania”, „tułanie się po świecie”, „brak pracy”, ,czekanie na lepsze jutro”.

Choroba i cierpienie mogą być z jednej strony: „okrutne”, „przykre”, „wyczerpujące”, „bolesne”, a z drugiej: „zapłatą za zło”, „pouczającym doświadczeniem”, „drogą do zrozumienia szczęścia”, „przełomem w życiu”, „próbą wytrzymałości”, „momentem na zastanowienie się nad sobą”.

\section{Odczuwanie bezradności i traktowanie pomocy innych ludzi}

$\mathrm{Na}$ ocenę stopnia bezradności pozwoliło zdanie czwarte w Skali PIL, które brzmiało: „Czasem myśląc nad swoim życiem, czuję się całkowicie bezradny, ponieważ..." Badane matki wykazały wysoki poziom bezradności, nie widząc przy tym możliwości przezwyciężenia tego stanu, chociażby poprzez pomoc innych ludzi.

Matki z obu grup czuły się bezradne, gdyż twierdziły, że ich życie legło w gruzach, w życiu nic im nie wychodzi, nie wiedzą, ile jeszcze porażek doznają w przyszłości, co je jeszcze czeka, czują się bezradne w sytuacjach samodzielnego podejmowania ważnych decyzji i wyborów oraz ich trafności. Obawy te pogłębiają: brak pieniędzy, pracy, mieszkania, możliwości „dania dzieciom tego, czego potrzebują”.

Pomimo że badane grupy matek różnią się między sobą tym, że część z nich zamieszkuje ze swoimi rodzinami, a druga - w DSM, analizy wykazały, że w jednakowy sposób spostrzegają one możliwości pomocy, a raczej ich brak, ze strony innych ludzi. Podkreślają, że samotność i brak wsparcia osób najbliższych (szczególnie w przypadku matek z DSM), a przy tym brak akceptacji i ignorancja innych osób sprawiają że poczucie bezradności, a tym samym nastawienie „od” życia ujawniają się jeszcze bardziej.

Można więc powiedzieć, że badane matki oczekują pomocy innych ludzi, nie traktując jej w kategoriach zbytecznej czy upokarzającej.

\section{Posiadanie nadziei}

O posiadaniu nadziei świadczyły opinie, które kończyły zdania: „Mam nadzieję, że potrafię...” oraz „Myśl o samobójstwie...”

Nadzieja jako wartość nie znalazła swojego miejsca w siedmiu możliwych wyborach w Skali Preferencji Wartości K. Popielskiego. Badane matki nie wymieniały jej jako jednej z najważniejszych dla nich wartości.

Część jakościowa PIL pozwoliła jednak na stwierdzenie, że pomimo sytuacji, w jakiej znalazły się badane kobiety, posiadają jeszcze nadzieję, chociaż o jej sile świadczyć mogą wypowiedzi dotyczące myśli samobójczych. Co do tej ostatniej kwestii, grupa matek z DSM wykazuje różnice wzglądem matek pozostających we własnych rodzinach. 
Generalnie matki z obu grup mają nadzieję, że potrafią: „podołać wszystkim obowiązkom, zadaniom i problemom”, „poradzić sobie w życiu w pojedynkę”, ,pokonać wszystkie przeszkody”, „być silną i wybrnąć z kłopotów”, „dojść do czegoś w życiu”, ,zrealizować swoje plany”, „znaleźć pracę”, „ułożyć sobie życie na nowo i uczynić je lepszym”, „walczyć o swoje”, „być samodzielna”, ,znieść wiele”, „być dobrą matką”, „,dobrze wychować dziecko i stworzyć mu dom”, „być wesołą, uśmiechniętą", ,jeszcze zaufać i pokochać".

Myśl o samobójstwie jest dla matek samotnych z DSM, z jednej strony: „głupia”, „nie rozwiązuje problemu”, ,jest chora”, „przerażająca”, „powoduje, że przechodzą ciarki".

Z drugiej strony $26 \%$ badanych matek przyznało, że myśl o samobójstwie: ,nachodzi mnie czasem”, „była mi bliska przez wiele lat”, „kiedyś tak, teraz już chyba nie”.

$\mathrm{Z}$ kolei matki z grupy drugiej kategorycznie odrzucają takie myśli. Są one dla nich: „straszne”, „przerażające”, „bez sensu”, „wyrazem tchórzostwa”.

Podsumowując przeprowadzoną analizę jakościową, dochodzimy do wniosku, że matki z obu grup wykazały podobieństwa $\mathrm{w}$ wypowiedziach dotyczących precyzowania swoich celów życiowych, stosunku do choroby, cierpienie i śmierci, a także odczuwania bezradności i oczekiwanej pomocy. Wykazały się także posiadaniem nadziei, choć to matki pozostające we własnych rodzinach kategorycznie odrzuciły myśli o samobójstwie. Wypowiedzi kobiet dotyczące stosunku do własnego życia dowiodły, że matki z grupy B określały go zdecydowanie pozytywniej.

\section{Zakończenie}

Sens nie jest dziedziczony ani przekazywalny. Nie jest wyuczalny. Nie sposób go zaprojektować czy przepisać na recepcie. Nie jest formą logiki. Nie jest do podarowania ani do kupienia. „Poczucie sensu jest ludzkim doświadczeniem najgłębszym i szczytowym, rzeczywistością samoistną, rzeczywistością i wartością samą w sobie”22.

Życie ma sens, jeżeli zostało tak ułożone, iż tworzy całość zmierzającą rozumnie ku zrealizowaniu celów najlepszych $\mathrm{z}$ tych, do których zrealizowania $\mathrm{w}$ danych warunkach jesteśmy zdolni. Aby nadać życiu sens w powyższym znaczeniu, trzeba, po pierwsze, umiejętności rozróżnienia tego, co naprawdę dobre i co dobre jedynie z pozoru, oraz tego, co lepsze i gorsze; po drugie zaś, trzeba wysiłku, aby dążyć wytrwale do obranych celów ${ }^{23}$.

Podsumowaniem rozważań na temat sensu życia niech będą słowa W. Siedlaka, który powiedział ${ }^{24}$ :

${ }^{22}$ K. Popielski, Doświadczenie sensu i jego znaczenie dla egzystencji, w: K. Popielski (red.), Człowiek-wartości-sens..., s. 60.

${ }^{23}$ T. Czeżowski, Jak rozumieć ,, sens życia”, w: Środa M. (oprac.), O wartościach, normach i problemach moralnych, Warszawa 1994, s. 346.

${ }^{24}$ W. Sedlak, Humanizacja biosu, w: K. Popielski (red.), Człowiek-pytanie otwarte..., s. 160. 
Szczęśliwy w pewnym sensie może być człowiek, dla którego nie istnieje problem sensu życia, jak na pewno jest szczęśliwy człowiek, dla którego nie istnieje kwestia zdrowia, ponieważ ono po prostu jest. Natomiast wielką udręką może być poszukiwanie sensu, który jednak musi mimo wszystko być własnym i najbardziej osobistym odkryciem. Sens to właśnie wypełniacz czasu przeszłego i przyszłego, czyli asekuracja przed wejściem w pustkę czasu teraźniejszego. Tym bowiem tylko człowiek dysponuje [...]. Sens życia to, praktycznie biorąc, produkcja jego człowieczeństwa.

\section{Gefuhl des Lebensinnes von alleinstehenden Mutter (Zusammenfassung)}

In diesem Aufsatz wurden die theoretische Analise betreff des Lebenssinnes und die Ergebnise von Untersuchungen des Lebenssinnes (PIL) J. C. Crumbaugh, L. T. Maholick (besonders Qualitätsanalise ) dargestellt. Man hat sie mit dem Anteilvon zwei Gruppen der minderjährigen, verlassenen Frauen durchgeführt. Alle waren nach dem Jahr 1975 geboren, hatten die Kinder bis 5 Lebensjahr. Die Frauen waren unter 18 Jahre im Moment des traumatischen Ereignisses-die Schwangerschaft. Die erste Gruppe (50 Personen) bildete die Mutter, die aus verschiedenen Gründen im Fürsorgeheim wohnten (A), die andere Gruppe - die Mutter (auch 50 Personen), die mit eigenen Familien und Kinder in Torun wohnten (B). Untersuchungen wurden in der Periode: Juli 1998 bis zum Marz 2000 durchgeführt. Die Skale des Gefühles vom Lebenssinn (PIL) J. C. Crumbaugh und L. T. Maholick besteht aus drei Teile: Teil A metrisches, es besitzt 20 Behauptungen mit der 7- Grad Skale -1 (sehr niedrig) bis zum 7 (sehr hoch) Um die Qualitätsanalise zu machen, erlauben die Teile B i C die Skale der Gefühles vom Lebenssinn. Diese Teile haben die Form nicht beendeten Sätzen. Die Inhaltähnlichkeiten zwischen manchen Sätzen hat man verbunden und folgten danach die Schlußfolgerungen: über die Beziehung zum Leben, den Ziel des Lebens, die Zufriedenheit, die Hoffnung, Ambition, den Sinn der Egsistenz, die Opferwilligkeit und die Interpretation der Hilfe anderer Menschen. Man hat bekommen folgende Gruppen der Behauptungen: Beziehung zum eigenen Leben, Lebensziele, Lebenszufriedenheit, Beziehung zur Krankheit, Leiden, Tod, Hilflosigkeit. Die Qualitätsanalise zeigte, es waren die Ähnlichkeiten in den Aussagen bei beiden Gruppen, gemäß Lebensziele, Beziehung zur Krankheit, Leden und Tod, Hilflosigkeit und Erwartung der Hilfe. Es gab auch viel Hoffnung in den Azssagen, doch die Mutter, die mit eigenen Familien leben, lehnten den Selbstmord ab. Die Mutter aus der Gruppe B beurteilten die Beziehung zum eigenen Leben mehr positiv. 